\title{
Hope in Africa? Social representations of world history and the future in six African countries
}

\author{
Rosa Cabecinhas ${ }^{1}$, James H. Liu $^{2}$, Laurent Licata ${ }^{3}$, Olivier Klein ${ }^{3}$, Júlio Mendes ${ }^{4}$, \\ João Feijó ${ }^{5}$, and Aline Niyubahwe ${ }^{6}$ \\ ${ }^{1}$ Instituto de Ciências Sociais, Universidade do Minho, Braga, Portugal \\ ${ }^{2}$ School of Psychology, Victoria University of Wellington, Wellington, New Zealand \\ ${ }^{3}$ Unité de Psychologie Sociale, Université Libre de Bruxelles, Brussels, Belgium \\ ${ }^{4}$ Instituto Superior de Ciências de Educação, Universidade Agostinho Neto, Luanda, Angola \\ ${ }^{5}$ Instituto Superior de Ciências do Trabalho e da Empresa, Instituto Universitário de Lisboa, \\ Portugal, and Centro de Estudos Africanos, Universidade Eduardo Mondlane, \\ Maputo, Mozambique \\ ${ }^{6}$ Faculté d'éducation, Université de Sherbrooke, Sherbrooke, Canada
}

\begin{abstract}
$D$ ata on social representations of world history have been collected everywhere in the world except subSaharan Africa. Two studies using open-ended data involving university students from six African countries fill this gap. In Study 1, nominations from Cape Verde and Mozambique for the most important events in world history in the past 1000 years were dominated by war and politics, recency effects, and Western-centrism tempered by African sociocentrism on colonization and independence. The first three findings replicated previous research conducted in other parts of the world, but the last pattern contrasted sharply with European data. Study 2 employed a novel method asking participants how they would begin the narration of world history, and then to describe a major transition to the present. Participants most frequently wrote about the evolution of humanity out of Africa, followed by war and then colonization as a beginning, and then replicated previous findings with war, colonization, and technology as major transitions to the present. Finally, when asked about how they foresaw the future, many participants expressed hope for peace and cooperation, especially those facing more risk of collective violence (Burundi and Congo). A colonial/liberation narrative was more predominant in the data from former Portuguese colonies (Angola, Cape Verde, and Guinea-Bissau) than from former Belgian colonies (Burundi and Congo).
\end{abstract}

Keywords: Collective remembering; Narrative templates; Social representations; Africa.

es données sur les représentations de l'histoire du monde ont été recueillies partout dans le monde sauf en
Afrique subsaharienne. Deux études utilisant des questions ouvertes posées à des étudiants d'université
provenant de six pays africains remédient à cette situation. Dans la première, les réponses provenant du Cap-Vert
et du Mozambique en ce qui concerne les événements les plus importants de l'histoire mondiale démontrent une
prépondérance de la guerre et de la politique, d'effets de récence et d'une centration occidentale tempérée par un
sociocentrisme africain se manifestant par des réponses sur la colonisation et l'indépendance. Les trois premiers
résultats sont conformes à ceux obtenus dans d'autres parties du monde, mais le dernier est fortement en décalage
avec les données européennes. La deuxième étude a utilisé une nouvelle approche demandant aux participants
comment ils commenceraient la narration de l'histoire mondiale avant de poursuivre avec la description d'une
transition majeure menant à la période présente. Le plus souvent, les participants présentent l'évolution de

Correspondence should be addressed to Rosa Cabecinhas, Instituto de Ciências Sociais, Universidade do Minho, Campus de Gualtar, 4710-057 Braga, Portugal. (E-mail: cabecinhas@ics.uminho.pt).

This work was partially supported by a Portuguese Science Foundation grant (SFRH/BSAB/1005/2010). We acknowledged Klaus Boehnke and two anonymous reviewers for their comments on a previous version of this paper. We would like to thank Michel Cibois for his very helpful insights in the use of correspondence analysis. We are grateful to Charles Lukanga, Eliseu Sueia, Lambert Ekanga, Nesilita Nhaga, and Silvino Évora for their support in data collection and to all students who voluntarily participated in this research.

(C) 2011 International Union of Psychological Science 
l'humanité à partir de l'Afrique suivie de la guerre puis de la colonisation comme commencement avant de reproduire les données antérieures sur la guerre, la colonisation et la technologie en tant que points de transition majeurs vers la situation présente. Finalement, lorsqu'on leur demande comment ils entrevoient l'avenir, plusieurs participants expriment leur espoir pour la paix et la coopération. Cela est vrai en particulier pour ceux qui font face plus que les autres à la violence collective (Burundi et Congo). Une narration centrée sur la colonisation et la libération est plus présente dans les données provenant des anciennes colonies portugaises (Angola, Cap-Vert et Guinée-Bissau) que dans les anciennes colonies belges (Burundi et Congo).

\begin{abstract}
$D$ atos acerca de las representaciones sociales de la historia del mundo se han recogido en todo el mundo salvo en el África subsahariana. Este vacío es llenado por dos estudios que utilizaron datos de respuestas abiertas y en los que participaron estudiantes universitarios de seis países africanos. En el Estudio 1, las respuestas de Cabo Verde y Mozambique de los eventos más importantes en la historia del mundo en los últimos 1000 años estuvieron dominadas por la guerra y la política, los efectos de lo reciente y el centrismo del mundo occidental moderado por el sociocentrismo africano respecto de la colonización y la independencia. Los tres primeros resultados replican los de investigaciones previas realizadas en otras partes del mundo, pero el último patrón contrastó marcadamente con los datos europeos. El Estudio 2 empleó un método novedoso preguntándoles a los participantes de qué forma comenzarían la narración de la historia del mundo, y luego pidiéndoles que describieran una importante transición hacia el presente. Los participantes escribieron con mayor frecuencia acerca de la evolución de la humanidad desde el África, seguida por las guerras y luego la colonización como un comienzo, y luego replicaron hallazgos previos con las guerras, la colonización y la tecnología como las transiciones importantes hacia el presente. Por último, cuando se les preguntó acerca de cómo prevén el futuro, muchos participantes expresaron esperanza en la paz y la cooperación, especialmente aquellos que se enfrentan a mayor riesgo de violencia colectiva (Burundi y Congo). La narrativa colonial o de liberación fue más predominante en los datos de las antiguas colonias portuguesas (Angola, Cabo Verde y Guinea Bissau) que en las antiguas colonias belgas (Burundi y Congo).
\end{abstract}

Outside of South Africa, Sub-Saharan Africa is a truly "dark continent" in terms of empirical research on its political and social psychology. Africa has been cruelly treated by the world in terms of its history of colonization by European powers, its poor record of postcolonization development, and in its quasi-absence from social psychological research. Given that "History provides us with narratives that tell us who we are, where we came from and where we should be going" (Liu \& Hilton, 2005, p. 537), representations of world history should be a fertile domain to engage in the task of better understanding how Africans narrate their own story.

Previous studies on social representations (Moscovici, 1988) of world history have been conducted all around the world except for subSaharan Africa (Liu et al., 2005, 2009). These studies have used open-ended (e.g., Deschamps, Paez \& Pennebaker, 2001; Liu et al., 2005, 2009; Pennebaker, Paez \& Deschamps, 2006) and closedended methods (Liu et al., in press). Given the lack of previous data from Africa we decided to use open-ended methods to uncover African narratives in their own right, without restrictions from item content derived from other regions. Furthermore, we introduce new open-ended questions in order to allow investigation not only of the content of social representations of world history from Africa, but also of the influence of different narrative templates (Wertsch, 2002) guided by three questions. First, will the data from Africa replicate the general patterns found in previous research? Second, are there any uniquely African perspectives on world history? Third, what is the impact of different narrative cues on the representations of world history? We also aimed to explore possible differences according to the countries' historical context.

\section{COLLECTIVE REMEMBERING OF WORLD HISTORY}

According to Halbwachs (1950/1997), human memory is not an individual but a social phenomenon. People can only remember things that are mediated by communication in their respective social groups and what they can accommodate in their existing social frames of reference. Extending Halbwachs, Wertsch (2002) considers collective remembering as "a form of mediated action, meaning that it is fundamentally distributed between active agents, on the one hand, and the cultural tools - especially narrative texts - that they employ, on the other" (p. 172). Thus, social representations of history are dynamically organized through narrative templates (Liu \& László, 2007; Wertsch, 2002). Narrative templates provide a tool for what Bartlett termed the "effort after meaning" (1932, p. 44). Wertsch (2002, p. 123) 
argues that the efficacy of narrative as a cognitive instrument is grounded in a moralizing impulse: Narrative provides a way of grasping together a set of events and people, not into some kind of neutral and objective representation; rather, in the creative "process of invoking an imaginary coherence, integrity, fullness, and closure, narrative also introduces a moral order into the picture" (Wertsch, 2002, p. 124).

Licata, Klein and Gély (2007) translate such narrative phenomena into a more psychological language of identity functions of collective memory: it contributes to the definition of group identity; it furnishes elements that can be used to achieve positive distinctiveness (by processes of selective remembrance and oblivion); it provides justifications for groups' actions (past, present, and future); and it enables collective mobilization by challenging the legitimacy and stability of the existing social order. As we shall see, each of these elements is reflected in African representations of world history.

\section{BIASES IN THE REMEMBRANCE OF WORLD HISTORY}

Previous research on the representations of world history, using open-ended measures, identified the following biases.

\section{Recency bias}

People tend to perceive recent events as more important than those that occurred long ago (Liu et al., 2005, 2009; Pennebaker et al., 2006). When asked about memories of traumatic and vivid events related to their relatives, people usually recollect events going only as far back as their grandparents (Pennebaker, Paez \& Rimé, 1997). Using free-recall measures in the remembrance of world history, Liu et al. (2009) found that the last 200 years accounted for $80 \%$ of events nominated across different cultures.

\section{Centrality of warfare and politics}

Previous free-recall data showed that wars, conflicts and revolutions were considered the most important events, whereas scientific, technological, and socioeconomic issues were underestimated (Liu et al., 2005, 2009). According to Liu and László (2007), conflict seems to be a basic template for storytelling, generating powerful emotions. Conflicts and war play a central role in nation building, being frequently considered the foundational events in a nation's history.

\section{Western-centric bias}

Previous studies on the remembrance of World history have evidenced a high level of crosscultural consensus, with important nominated events being mainly related to Europe and North America. "Dominant social representations of history appear to be the representations of dominant nations and cultures, i.e. Western nations" (Liu et al., 2009, p. 687). Thus, representations of world history reproduce the current state of world power relations.

\section{Sociocentric bias}

Participants tend to consider nationally relevant historical events as more important than those that do not refer to their country (Deschamps et al., 2001; Liu et al., 2005, 2009). Overall, Western countries consistently have reported very few events that occurred outside of their own region, whereas non-Western countries reported many events related to Western countries but also exhibited some ethnocentrism with respect to the events related to their own state.

We might expect these patterns to be replicated in sub-Saharan Africa, but some developments counter these tendencies. During the past few decades, new African historiography has developed. One of the priorities of African liberation movements has been to rewrite history to overcome Eurocentric perspectives and decolonize people's minds (Cabecinhas \& Feijó, 2010). In Angola, Mozambique, and other African nations, postindependence interpretations of history (Feijó, 2009) have emerged denouncing the exploitation of the colonies as a result of asymmetrical social and power relations, and present Africa as the cradle of humanity. Hence, we might expect a more Afrocentric view to emerge from young African university-educated elites.

\section{SUB-SAHARAN AFRICA: POLITICAL AND SOCIO-ECONOMIC CONTEXT}

Given the central role that context plays in the dynamics of collective memory, it is pertinent to present a short historical overview and describe the present-day situation of the six sub-Saharan African countries where this research was conducted: Angola, Burundi, Cape Verde, 
Democratic Republic of Congo, Guinea-Bissau, and Mozambique.

Until the mid-1950s colonialism was still firmly established in Africa. According to Stengers (1989, p. 200), in 1956 the colonial order in Belgian Congo was "so stable, assured, rock-solid that political perils were viewed as very unlikely." This was also the case in Portuguese Africa. Most of the future liberation leaders (for example, Patrice Lumumba in Congo and Amílcar Cabral in Cape Verde and Guinea-Bissau) adhered to the colonial project. However, their faith in the colonial system started to falter when local elites "realized that in spite of the many efforts required for attaining a higher status, they remained 'Blacks' in the eyes of the Belgians and were still denied social recognition" (Klein \& Licata, 2003, p. 576), and independence was achieved by other African states (Ghana 1957, Guinea 1958, Senegal 1960, etc.). Meetings between influential African nationalistic and pan-African leaders led to the creation of the Organization of African Unity (established on 25 May 1963, transformed into the African Union in 2002).

In the language of social identity theory (Tajfel \& Turner, 1979), "cognitive alternatives" to colonialism emerged in the course of the 1950s and the European colonizers' "position began to be perceived as illegitimate and unstable and they became a salient, negatively valued, out-group" (Klein \& Licata, 2003, p. 587). Congo achieved rapid independence after three years of negotiations with Belgium in 1960, whereas Burundi gained its independence in the context of interethnic violence in 1962, but also without meeting much resistance (Weinstein \& Schrire, 1976). In contrast, for the former Portuguese African colonies, independence was obtained only after a long liberation war that started in Angola in 1961, spread to Guinea-Bissau and Mozambique, and did not conclude until the Carnation Revolution in Portugal in 1974.

Since independence, these countries, except Cape Verde, have experienced periods of interethnic violence or/and civil war, which undermined their development with devastating consequences. According to the United Nations Development Programme (2009), sub-Saharan Africa is the region in the world with the lowest human development level. The Democratic Republic of the Congo is in 176th position of 182 in the Human Development Index ranking $(\mathrm{HDI}=0.389)$; Burundi appears in 174 th position $(\mathrm{HDI}=0.394)$, behind Guinea-Bissau (173: HDI $=0.396$ ), and Mozambique (172: HDI $=.402)$. Angola appears higher up at $143(\mathrm{HDI}=0.564)$. All of them are categorized as Low Human Development countries. Cape Verde is in 121st position (HDI $=0.708)$, being considered a Medium Human Development country since 2008 .

\section{STUDY 1}

In Study 1 we asked participants from two African countries to free-recall the most important events in world history in the past 1000 years, as in prior research (Liu et al., 2009). We had three hypotheses involving the replication of previous findings in an African context.

H1: Participants would mention more events related to Europe and North America in comparison to events not involving directly Western countries (Western-centric bias), but this will be complemented by a tendency to mention events linked to ethnic, national, and regional ingroups (sociocentric bias). We surmised that colonization issues would be particularly important in the African context. This affords an African perspective on world history that puts the blame for negative effects on an externally imposed past instead of the failings of the ingroup, which serves social identity protection functions.

H2: Wars and conflicts would be mentioned more often than other kinds of events, such as science, technology, and socioeconomic issues (centrality of warfare and politics).

H3: Most nominated events would be recent ones, occurring within the past 100-200 years (recency bias).

\section{Method}

In Cape Verde and Mozambique, a questionnaire-identical to that reported in Liu et al. (2009) — was administered to university students. University students are ideal for this kind of study, as their representations of world history reflect a strong institutional (educational) component that allows comparability with data from other parts of the world.

\section{Procedure}

Surveys were administered in university classrooms to students in various disciplines, except history, who participated on a voluntary basis. Those are nonprobabilistic samples, and cannot be considered representative of the whole populations of their respective countries. 
The cover page explained to participants that we were interested in their personal opinions about history, rather than their factual knowledge. Students completed surveys in Portuguese, the standard language of instruction. Data were collected in Cape Verde in 2007 and in Mozambique in 2009.

\section{Participants}

Three hundred and one university students participated in this study: 121 Cape Verdeans (57 women and 64 men; age $M=23.19, S D=5.13$ ) and 180 Mozambicans (99 women and $81 \mathrm{men}$; age $M=26.59, S D=6.63)$.

\section{Survey questions}

Following Liu et al. (2005), participants were asked to list the five events they considered to have been most important in world history in the past 1000 years. No list of events was presented, so recall was free. The categorization of events followed protocols established in previous research (Liu et al., 2005). Participants then had to rate the evaluation of each event using a seven-point scale, from 1 (very negative) to 7 (very positive).

\section{Results and discussion}

Table 1 displays the Top 10 events spontaneously listed by Cape Verdeans and Mozambican participants when thinking about the most important events in world history in the past 1000 years.

The most obvious feature of Table 1 is the prominence of Western-centrism: Events related to Europe and North America, and global events where Western nations played a central role, appear at the top in both countries. In Cape
Verde almost all events in the top 10 occurred in Western countries or were related to Western dominance (see Liu et al., 2005, 2009), with only two exceptions: the abolition of slavery and the Asian tsunami. In Mozambique, Western-centrism was evident in more than half of the events, with the other big cluster of events being related to colonialism and human rights issues. Hypothesis 1 was confirmed.

In accord with Hypothesis 2, the World Wars were the most frequently nominated events in world history. The data replicated Liu et al.'s (2005, 2009) findings, confirming that history is also perceived as a story about war and politics in sub-Saharan Africa. However, these two categories of events accounted for an average of $56 \%$ of participants' nominations, which is less than the $75 \%$ observed in previous research.

This difference was accounted for by the high levels of colonization-related nominations in Cape Verde and Mozambique (19\% and 18\% respectively, and coded separately from politics and war in accordance with previous research: This represented only $2 \%$ in Liu et al., 2009). Colonialism was perceived as very negative and the end of colonialism as very positive, supporting a more Afro-centric interpretation of these events.

Slavery issues had greater salience than in most international data except Brazil (Liu et al., 2009), which also has a history of slavery. Abolition of slavery was mentioned by $18 \%$ of the Cape Verdeans and $6 \%$ of Mozambicans participants, and slavery was nominated by $8 \%$ of Mozambicans and $6 \%$ of Cape Verdeans. The abolition of slavery was considered an unambiguously positive event, while slavery was considered consensually as the most negative event.

The Berlin Conference, which shaped presentday African country borders according to European colonial interests of $1884 / 5$, was

TABLE 1

Top 10 events in world history (last 1000 years)

\begin{tabular}{|c|c|c|c|c|c|c|c|}
\hline Cape Verde $(N=121)$ & $\%$ & Mean & $(S D)$ & Mozambique $(N=180)$ & $\%$ & Mean & $(S D)$ \\
\hline WWII & 63 & 1.22 & $(1.51)$ & WWI & 61 & 2.16 & $(1.80)$ \\
\hline WWI & 57 & 1.70 & $(1.28)$ & WWII & 46 & 2.20 & $(1.81)$ \\
\hline 9/11 World Trade Center (WTC) & 41 & 1.31 & $(1.03)$ & Industrial Revolution & 26 & 6.78 & $(0.83)$ \\
\hline Industrial Revolution & 19 & 6.42 & $(1.01)$ & African independence & 24 & 6.76 & $(0.78)$ \\
\hline Abolition of slavery & 18 & 7.00 & $(0.00)$ & Colonialism & 19 & 2.71 & $(1.79)$ \\
\hline Fall of Berlin Wall & 16 & 1.46 & $(0.43)$ & 9/11 WTC & 18 & 2.76 & $(2.62)$ \\
\hline Iraq War & 14 & 4.85 & $(2.07)$ & Obama victory & 14 & 6.58 & $(1.22)$ \\
\hline Asian tsunami & 14 & 1.27 & $(0.43)$ & French Revolution & 13 & 6.62 & $(1.29)$ \\
\hline End of colonialism & 12 & 6.80 & $(0.75)$ & Berlin Conference & 12 & 3.30 & $(2.22)$ \\
\hline Cape Verde independence & 12 & 6.56 & $(0.78)$ & Creation of UN & 11 & 7.00 & $(0.00)$ \\
\hline
\end{tabular}

$\%=$ Percentage of respondents that nominated an event. 
mentioned by $12 \%$ of Mozambicans but not by Cape Verdeans, perhaps because, being an island archipelago, its borders were not defined by the conference outcomes.

Events related to the promotion of human rights and equal opportunities for all were evident in the top 10 in Mozambique, such as the French Revolution $(13 \%)$, the founding of the United Nations (11\%) and Obama's victory (14\%). Outside of the top 10, events related to apartheid were also salient in Mozambique: apartheid (8\%), imprisonment and liberation of Nelson Mandela (respectively, $3 \%$ and $4 \%$ ), end of apartheid (3\%).

In sum, a subset of events related with the promotion of human rights and struggle for freedom and independence was much more salient in African data than in Western or Asian data (see Liu et al., 2005, 2009). The kind of sociocentrism observed in these African samples was closer to a pan-African agenda than to a nationalist one, as participants privileged events related to the "common fate" of suffering and oppression from colonial rule and the African struggle for freedom, human rights, and independence.

Finally, there was a strong recency effect (Hypothesis 3). Most of the nominated events occurred in the 20th or 21 st centuries, and together the last 200 years accounted for more than $90 \%$ of events nominated on average (compared to $80 \%$ in Liu et al., 2009). This huge recency effect can be explained by the fact that most Africans have nearly no knowledge of their precolonial history, because there was no written material, and also because the Europeans imposed a Western-centric view of history, sometimes destroying evidence of African civilizations (Said, 1985).

Summing up, results from two African samples confirmed the major previous findings, with representations of world history being: (1) characterized by Western-centrism complemented by some sociocentrism (at a national and/or regional level), (2) a story about war and politics, and (3) focused on the present and recent past.

Data confirmed the "apparently universal structure in the representation of world history, characterized by a focus on politics and war, sociocentrically projected from the present to the past" (Liu et al., 2009, p. 687) and were anchored by the World Wars, 9/11, colonialism and the struggle for freedom and independence in Africa.

\section{STUDY 2}

To ascertain if the kind of content found in Study 1 was contingent on the methods used, an alternative set of three eliciting questions was used in the second study with a broader set of nations, allowing also an exploration of the influence pertaining to two different historicalcultural contexts: former Belgian and former Portuguese colonies. In this study, conducted in five African countries, a new open-ended method allowed participants to write complete and complex sentences to produce an overall narrative rather than just listing discrete events and people. Three questions, concerning the beginning, middle, and future of world history, were used to examine whether different questions might reveal different content in terms of historical narratives. Besides the hypotheses mentioned for Study 1, we expected that:

\begin{abstract}
H4: The predominant narratives would vary depending on the eliciting question. We assumed that using a question about beginnings would elicit narratives concerned with the evolutionary origins of humanity coming out of Africa, putting Africans in a more central position in the story.
\end{abstract}

We also aimed to explore possible differences according to the countries' historical context; i.e., we surmised that a colonial/liberation narrative would be more predominant in former Portuguese than former Belgium colonies, since the decolonization process was slower, more violent, and more recent than in the former Belgian colonies.

\section{Method}

\section{Participants}

A total of 865 university students - in various disciplines, except history-from five African countries participated in the study: Angola, Cape Verde, Guinea-Bissau (using Portuguese), Burundi, and Congo (using French), Portuguese and French being respectively the standard languages of instruction at their universities. Participants who did not answer any of the open-ended questions of interest were discarded (4 Angolans, 7 Cape Verdeans, 4 Guineans, 18 Congolese, and 9 Burundians). The final dataset included 822 participants: 180 Angolans (43.3\% female; age $M=21.07, S D=4.21) ; 186$ Burundians (46.2\% female; age $M=24.58$, $S D=3.09) ; 124$ Cape Verdeans (61.3\% female; age $M=24.63, S D=5.83) ; 162$ Congolese $(26.5 \%$ female; age $M=28.64, \quad S D=8.51) ;$ and 170 Guineans $(24.1 \%$ female; age $M=26.56$, $S D=6.21)$. Those are nonprobabilistic samples 
TABLE 2

Beginning a narration of world history

\begin{tabular}{|c|c|c|c|c|c|c|}
\hline Beginning Categories \% & Angola & Burundi & Cape Verde & Congo & Guinea-Bissau & Total \\
\hline Evolution & 22 & 47 & 21 & 36 & 9 & 28 \\
\hline Religion & 2 & 12 & 5 & 22 & 6 & 10 \\
\hline Wars and conflicts & 32 & 6 & 26 & 5 & 38 & 21 \\
\hline Peace and cooperation & 1 & 0 & 3 & 1 & 1 & 1 \\
\hline Culture and society & 9 & 18 & 2 & 9 & 4 & 9 \\
\hline Technology & 9 & 1 & 9 & 3 & 11 & 6 \\
\hline Colonization & 22 & 1 & 35 & 3 & 26 & 16 \\
\hline Political & 3 & 2 & 5 & 1 & 4 & 3 \\
\hline Environmental & 0 & 0 & 0 & 0 & 1 & 0 \\
\hline Economic issues & 0 & 3 & 0 & 4 & 1 & 2 \\
\hline Others & 0 & 2 & 0 & 3 & 0 & 1 \\
\hline Total $N$ answers & 180 & 171 & 131 & 141 & 172 & 795 \\
\hline
\end{tabular}

Columns may not sum to $100 \%$ because participants could mention more than one event.

and cannot be considered as representative of the whole populations of their respective countries.

\section{Procedure}

Participants were recruited in university classrooms and asked to voluntarily participate in a study about world history. After some sociodemographic questions, the cover page of the survey ended with three open-ended historical narrative questions: (1) If you had to tell the story of world history, how would you begin? (2) What do you think happened in history that was most important to bring us to the current state of the world? (3) What sort of future do you foresee for the world? Each question was followed by a blank space, allowing the participant to freely write several sentences.

\section{Coding scheme}

Participants typically wrote a sentence or two in response to each question. Following an adaptation of Liu et al.'s (2005) coding scheme, responses were coded into one of the following categories: (1) evolution, (2) religion, (3) wars and conflicts, (4) peace and cooperation, (5) culture and society, (6) technology, (7) colonization, (8) political, (9) environmental concerns, (10) economic issues, (11) others (instructions available on request). Multinomial analysis of variance using a maximum likelihood chi-square test statistic was employed on these categorical data (Woodward, Bonnett, \& Brecht, 1990). We also performed a correspondence analysis using the software Trideux 5.0 (Cibois, 2006) to examine the associations between occurrences of the content categories in each of the three eliciting questions.

\section{Results and discussion}

\section{Beginning the narration of world history}

When participants were asked how they would begin "the story of the world" (Q1) references to evolution were more frequent than references to war and conflict, $\chi^{2}(1)=7.57, p<.01$. The most frequent open-ended responses in this category were references to the "evolution of humanity" (Table 2). Examples of these answers ${ }^{1}$ were:

- "I would start by the African continent, where the first men were born" (Angolan/1)

- "Evolution of humankind and first tribes" (Guinean/49)

- "The origin of humankind and the way of life of primitive men" (Cape Verdean/2)

- "I would start by the cradle of humanity that is Africa" (Congolese/67)

- "I would start the history of Man, where he came from, how he multiplied and formed societies that could be antagonistic" (Burundian/64)

Warfare was the second most frequent narrative beginning - with the First World War (WWI) and Second World War (WWII) topping the nominations - but this was more frequent in the former Portuguese colonies (Angola, Cape Verde, and Guinea-Bissau) than in the former Belgian ones, $\chi^{2}(1)=120.06, \quad p<.001$. One can only speculate on the reasons for this difference. The long liberation wars in Angola and Guinea-Bissau leading to independence could account for the salience of this theme. Congo and Burundi went through even more recent episodes of violent conflicts but, in contrast to Portuguese former 
TABLE 3

Historical transition to the present

\begin{tabular}{|c|c|c|c|c|c|c|}
\hline Middle Categories $\%$ & Angola & Burundi & Cape Verde & Congo & Guinea-Bissau & Total \\
\hline Evolution & 5 & 3 & 5 & 2 & 4 & 4 \\
\hline Religion & 7 & 9 & 4 & 3 & 2 & 5 \\
\hline Wars and conflicts & 27 & 33 & 15 & 44 & 34 & 31 \\
\hline Peace and cooperation & 2 & 4 & 2 & 1 & 4 & 3 \\
\hline Culture and society & 7 & 8 & 5 & 11 & 3 & 7 \\
\hline Technology & 21 & 16 & 27 & 10 & 19 & 18 \\
\hline Colonization & 24 & 22 & 26 & 11 & 23 & 21 \\
\hline Political & 6 & 2 & 10 & 3 & 7 & 5 \\
\hline Environmental & 1 & 0 & 1 & 0 & 0 & 0 \\
\hline Economic issues & 1 & 2 & 2 & 10 & 5 & 4 \\
\hline Others & 2 & 0 & 0 & 4 & 0 & 1 \\
\hline Total $N$ answers & 180 & 184 & 119 & 160 & 170 & 813 \\
\hline
\end{tabular}

Columns may not sum to $100 \%$ because participants could mention more than one event.

colonies, these conflicts were not part of the origin of their present-day nations (see Liu et al., 2009), and are therefore not seen as a beginning.

The third most frequent category to start the narrative was colonization. The most frequent nominations in this category were issues related to slavery, colonialism and independence of African nations in general or their country in particular:

- "I would start by talking about slavery, colonization, independence, and then after the independence" (Congolese/138)

- "Once upon a time in 1961 [independence]" (Burundian/45)

- "What is the beginning of everything, in my opinion, is slavery and the triangular trade" (Guinean/13)

- "The liberation of Angola and the expulsion of the Portuguese" (Angolan/69)

- "I would start by the race competition from European countries to Africa" (Guinean/33).

Content pertaining to a colonial narrative was the second most frequent category for Portuguesespeaking countries, while in the French-speaking countries there were almost no references to colonial issues to begin the narrative, $\chi^{2}(1)=130.81, p<.001$. A possible explanation for the preponderance of colonial narratives in the Portuguese-speaking countries could again be the fact that the decolonization process was very slow and was achieved only after a long liberation war (1961-1974), while in the former Belgian colonies there was a rapid and mostly peaceful decolonization process.

\section{Historical transition to the present}

Table 3 reports answers to the second question (Q2): "What do you think happened in history that was most important to bring us to the current state of the world?" This question generated the most similar pattern of responses among the five countries, and replicated the general patterns found by Liu et al. (2005, 2009). When thinking about the transitions that help explain today, participants evoked mainly wars, especially the two World Wars.

Colonization was the second more important category. References to slavery and the slave trade, to the Berlin Conference (partitioning Africa among European powers), and to independence were the most frequent open-ended responses in this category:

- "Abolition of the slave trade" (Angolan/21)

- "The Berlin Conference and the division of Africa" (Guinean/61)

- "Our freedom in 1975 [independence]" (Cape Verdean/57)

- "The independence of my country" (Burundian/46)

- "June 30th 1960, date of the independence" (Congolese/54).

Technology was the third most important category. References to the Industrial Revolution, advances in medicine, and the advent of new information and communication technologies were most frequent.

- "The most important event that lead us to the present state of the world is the discovery of the machine by Man (18th century)" (Congolese/5) 
TABLE 4

Future foreseen

\begin{tabular}{|c|c|c|c|c|c|c|}
\hline Future categories $\%$ & Angola & Burundi & Cape Verde & Congo & Guinea-Bissau & Total \\
\hline Evolution & 1 & 1 & 1 & 1 & 1 & 1 \\
\hline Religion & 7 & 3 & 2 & 4 & 1 & 4 \\
\hline Wars and conflicts & 34 & 13 & 24 & 9 & 34 & 21 \\
\hline Peace and cooperation & 11 & 50 & 11 & 49 & 21 & 29 \\
\hline Culture and society & 11 & 10 & 11 & 20 & 5 & 11 \\
\hline Technology & 3 & 9 & 18 & 9 & 14 & 10 \\
\hline Colonization & 1 & 3 & 1 & 0 & 1 & 1 \\
\hline Political & 3 & 3 & 3 & 5 & 5 & 4 \\
\hline Environmental & 34 & 4 & 25 & 4 & 4 & 14 \\
\hline Economic issues & 3 & 4 & 3 & 7 & 5 & 4 \\
\hline Others & 1 & 2 & 5 & 3 & 3 & 2 \\
\hline Total $N$ answers & 185 & 182 & 129 & 177 & 159 & 832 \\
\hline
\end{tabular}

Columns may not sum to $100 \%$ because participants could mention more than one event.

- "Invention of the printing press" (Burundian/ 23)

- "The most important event is the advent of new technologies of communication" (Guinean/95).

These results suggest that when thinking about the most important events in world history in general, people are implicitly thinking about events with a causal impact on the present. In some cases, the participants made the causal link explicit:

- "The World War 2 that gave access to the universal declaration of human rights" (Angolan/63)

- "The Industrial Revolution, with the advent of steam power, decreased hard labor" (Angolan/ 6)

- "Colonization that brought division" (Burundian/15).

\section{Future foreseen}

When answering the question "What sort of future do you foresee for the world?" the most frequent category was Peace and Cooperation:

- "That wars cease in the world, that there be peace" (Burundian/23)

- "A future where friendship and dialogue between states reign" (Congolese/3)

- "A world with more justice, more equitable and humane, which promotes greater wellbeing for all" (Cape Verdean/78)

- "All people will understand each other, a better future" (Guinean/12)

- "A world without borders" (Cape Verdean/57)
- "There will be peace and everyone will live at ease" (Angolan/48).

Curiously, Burundi and Congolese participants, whose present-day political situation is more unstable and has a higher risk of collective violence, had a more optimistic narrative of the future. Participants seemed to project their aspirations for the present into the future (Table 4).

The second most frequent category when thinking about the future was warfare. Most of the open-ended responses in this category described a "third world war" and/or "complete destruction" due to "extreme competitiveness," "excessive greed and ambition," but also due to the "lack of water for all." Many participants made statements that the third world war will be a "water war."

The fourth most frequent category was culture and society issues, containing mainly references to changes in world power relations. Some participants anticipated the maintenance of Western world dominance ("Europeans will continue to interfere in the affairs of African people") but the majority mentioned shifts in world power: "end of the supremacy of the USA"; "intellectual supremacy of blacks over whites". References to shifts in power relations were particularly prevalent in Angola: About 12\% of the Angolan participants anticipated that Angola would become a world power in the future. This hope can be grounded in the fact that the country, rich in oil and diamonds, has experienced huge economic growth since the end of civil war in 2002.

Improvements in sciences and technology emerged as another important category of responses giving hope for the future. References to a "cure for AIDS" were among the most 
frequent in this category. On the other hand, references to environmental issues were part of a more pessimistic narrative, with mentions of climate change, natural catastrophes, and environmental degradation, which eventually would bring the "end of the world."

The question about the kind of scenarios participants foresaw for the future produced the most divergent results between countries. The participants in the former Portuguese colonies anticipated war and conflicts (a third world war, water wars, etc.) and environmental degradation (climate change, lack of water and other natural resources) more often than those in the former Belgian ones, $\chi^{2}(1)=60.24, p<.001$ for wars and $\chi^{2}(1)=77.83, p<.001$ for environment.

\section{Content categories according to eliciting question}

Overall results concerning the content categories across the five countries according to the eliciting question are in accordance with our hypotheses (cf. totals of Tables 2, 3, and 4). Events related to wars and conflicts were most frequently nominated when participants thought about world history (Hypothesis 2). However, the extent of the predominance of warfare and conflicts depended on the question cueing recall (Hypothesis 4). Participants showed a stronger tendency to evoke wars and conflicts when answering the middle question about transition to the present. When asked how they would begin the story of world history, participants' references to war and conflict were less frequent than references to evolution. The category on peace and cooperation received very low percentages on questions about the past, but this increased considerably when participants were foreseeing the future.

To examine the relationship between the content categories resulting from different eliciting questions, we performed a correspondence analysis. A matrix crossing the 10 content categories (excluding nonresponses and "others") with the three time periods defined by the eliciting questions ("beginning," "middle," and "future") was first constructed. Each cell of the matrix contained the number of observations associated with this crosstabulation of levels of the two variables, thereby yielding a contingency table. As expected, the observed frequencies deviated strongly from independence, $\chi^{2}(18)=1226, p<.001$, indicating that the content categories were not equally represented for each eliciting question (Hypothesis 4). To summarize the origin of these deviations, this table was subjected to a factorial correspondence analysis using SPSS's correspondence function. This method (see Benzecri, 1992; Cibois, 2009; Greenacre, 2007) is equivalent to a principal components analysis (PCA) but applies to categorical data. Rather than explaining correlation patterns, it attempts to account for deviations from independence in a contingency table through orthogonal factors summarizing these deviations.

This analysis yielded a strong first factor that explained $75 \%$ of the inertia (equivalent to "variance" in PCA parlance). An important aspect of this method is that both dimensions of the original table (here the time period and content categories) should be considered in relation to the factors extracted. The position of each of the time periods is represented in Table 5, and the position of the 10 content categories is presented in Table 6 . With respect to the time period, we find that the first factor contrasted the "future" (associated with the positive pole; see first column of Table 5) with the "beginning" (associated with the negative pole). With respect to the content categories, it opposed the evolution and colonization categories (typically used in the "beginning" question) on its negative pole to environmental concerns and peace and cooperation (typically used in the future) on its positive pole (see first column of Table 6).

A second factor explained the remaining 25\% of the inertia. With respect to the "time" question, it opposed the "middle" category to the two other categories (see right-hand part of Table 5). In terms of content, it mainly opposed technology and to a lesser extent colonization and economy (typically used in the "middle" question) to the category primarily used in the beginning, evolution of humanity.

TABLE 5

Relative positions of the three time periods on the factor correspondence analysis

\begin{tabular}{|c|c|c|c|c|c|}
\hline \multirow[b]{3}{*}{ Time } & \multicolumn{4}{|c|}{ Factor } & \multirow[b]{3}{*}{ Inertia } \\
\hline & \multicolumn{2}{|c|}{$I$} & \multicolumn{2}{|c|}{$I I$} & \\
\hline & $F^{*}$ & $\operatorname{Mass}^{* *}$ & $F^{*}$ & Mass** & \\
\hline Beginning & -0.76 & 0.31 & 0.62 & 0.36 & 0.15 \\
\hline Middle & -0.33 & 0.06 & -0.79 & 0.60 & 0.09 \\
\hline Future & 1.05 & 0.63 & 0.18 & 0.03 & 0.23 \\
\hline Total & & 1.00 & 1.00 & 1.00 & 0.47 \\
\hline
\end{tabular}

*Reflects the position of the Time period on the Axis (equivalent to "factor score" in PCA). **Reflects the contribution of the time period to the factor (i.e., the extent to which each time period contributes to defining the factor). 
Figure 1, which plots the position of each period and content category on the two factors (labeled "Dimension 1" and "Dimension 2"), presents a graphical representation of this analysis.

TABLE 6

Relative positions of the 10 content categories on the factor correspondence analysis

\begin{tabular}{|c|c|c|c|c|c|}
\hline \multirow[b]{3}{*}{ Content } & \multicolumn{4}{|c|}{ Factor } & \multirow[b]{3}{*}{ Inertia } \\
\hline & \multicolumn{2}{|c|}{$I$} & \multicolumn{2}{|c|}{$I I$} & \\
\hline & $F^{*}$ & Mass $^{* *}$ & $F^{*}$ & Mass** & \\
\hline Evolution & -1.10 & 0.22 & 1.25 & 0.50 & 0.14 \\
\hline Religion & -0.45 & 0.02 & 0.36 & 0.02 & 0.01 \\
\hline War & -0.09 & 0.00 & -0.31 & 0.07 & 0.01 \\
\hline Peace & 1.46 & 0.38 & 0.36 & 0.04 & 0.15 \\
\hline Culture & 0.17 & 0.00 & 0.27 & 0.02 & 0.00 \\
\hline Technology & 0.00 & 0.00 & -0.71 & 0.17 & 0.02 \\
\hline Colonization & -0.79 & 0.13 & -0.50 & 0.09 & 0.06 \\
\hline Political & 0.07 & 0.00 & -0.42 & 0.02 & 0.00 \\
\hline Environment & 1.63 & 0.23 & 0.53 & 0.04 & 0.09 \\
\hline Economic & 0.33 & 0.01 & -0.30 & 0.01 & 0.00 \\
\hline Total & & & & & 0.49 \\
\hline
\end{tabular}

* Reflects the position of the content category on the factor. $* *$ Reflects the contribution of the 10 content categories to each factor (i.e., the extent to which each content category contributes to defining the factor).
One can detect the co-occurrence of levels of different variables (here time and content category) visually by inspecting the difference in the angle they form with the origin (Cibois, 2009). A $90^{\circ}$ angle indicates perfect independence whereas acute and obtuse angles would suggest a positive and a negative interdependence, respectively. According to this logic, three large clusters can be identified on the graph as a function of the time period. One (upper left quadrant) associates the beginning with evolution and (to a lesser extent) religion. A second set associates the middle period with technology, colonization, war and conflict, and economy (lower part of the graph), and the third associates the future with peace and cooperation, and environmental concerns (upper right quadrant).

We also examined whether there was an association between the five countries and this factor structure by entering country as a supplementary variable. ${ }^{2}$ This analysis showed that participants did not exhibit specific associations with these two factors as a function of their nationality: The factor scores were all negligible. Note that this outcome is not incompatible with the existence of dependences between specific countries and particular levels of the categories

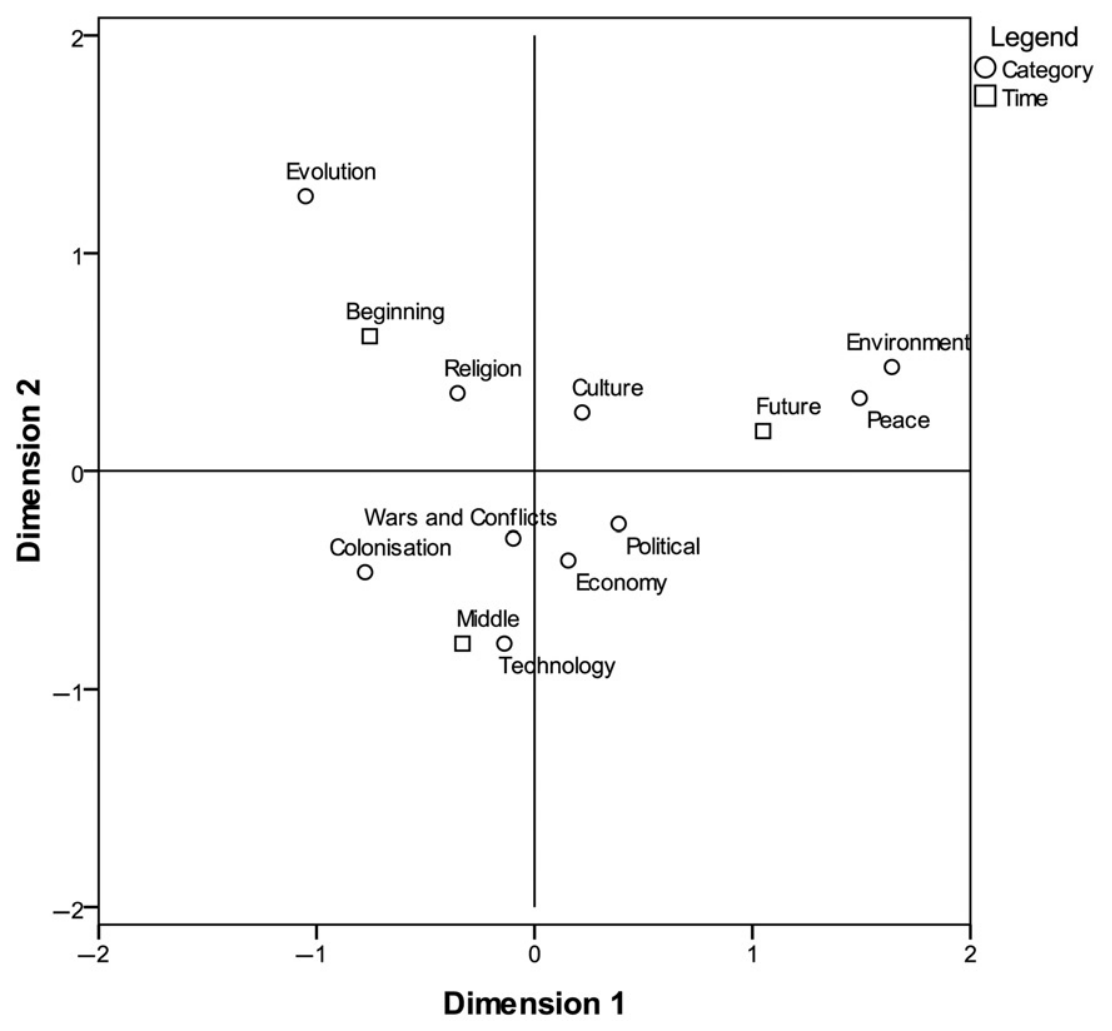

Figure 1. Graphic representation of the two factors of the correspondence analysis. 
but indicates that these are orthogonal to the factor structure describing the present matrix.

\section{GENERAL DISCUSSION}

Social representations of world history were analyzed in two studies using qualitative data involving university students from six sub-Saharan African countries. Study 1 showed that nominations from Cape Verde and Mozambique for the most important events in world history in the past 1000 years were dominated by war and politics, recency effects, and Western-centrism tempered by Afro-centrism surrounding colonization and independence. These patterns replicated previous research for the most part, but themes of human rights and struggle for freedom and independence, as well as those of colonization and slavery, were more salient than in European and Asian data (Liu et al., 2005, 2009).

Study 2 employed a novel method of asking participants how they would begin the narration of world history (Q1), to describe a past event that shaped the present $(\mathrm{Q} 2)$, and then foresee the future (Q3). Different eliciting questions triggered somewhat different narratives, but the one anchored in war (mainly the WWI and WWII) was strong regardless of the eliciting question.

Besides replication of the war and politics narrative, a new narrative of the evolution of humanity emerged using the new eliciting questions. Three main clusters were found: one associates the "beginning" with evolution and religion (to a lesser extent); a second associates the "middle" period of transition to the current situation with technology, colonization, war and conflict, and economics; and a third factor associates the future with peace and cooperation, and environmental concerns.

The need for closure and the "moralizing" impulse of the narrative (Wertsch, 2002) were also visible; sometimes participants expressed this explicitly, as when an Angolan began his narration with the "Arrival of Portuguese in Angola" (Q1), transitioned to the present by the "slave trade" (Q2), and foresaw a shift in world power-a reversal whereby "the current powers will be the most needy countries, because they are badly using their resources and discoveries" (Q3).

When asked about how they foresaw the future, most of the participants expressed hope for peace and cooperation, while a significant minority had a more pessimistic vision shaped by war and conflicts or environmental degradation. It was surprising that participants from war torn states had more optimistic views of the future. These "positive illusions" (Taylor \& Brown, 1988) might be a coping mechanism for difficult times.

As we expected, colonial/liberation emerged as a major narrative. This was particularly evident in former Portuguese colonies, probably because the decolonization process was slower, more violent, and more recent than in the former Belgian colonies. Differences between the former Portuguese and former Belgian colonies demand further exploration.

As mentioned above, colonial/liberation issues were highly salient in both studies, contrasting sharply with the previous results obtained in former European colonial powers. While Europeans tend to "forget" the dark side of colonization when thinking about world history, Africans render it salient. In both cases, forgetting or remembering it serves identity protection functions.

Several recent studies have shown the pervasiveness of the undermining effects of colonial processes in the formation of mentalities and on the shaping of present-day intergroup relations and stereotypes content (e.g., Volpato \& Licata, 2010). The long-term oppressive effects of colonialism are often underestimated in social psychological research, contributing to its pervasiveness. By rendering salient a colonial narrative, the participants acknowledge its effects in the present-day situation. Further research could investigate the relation of representations of world history and the attitudes towards reparation actions for historically disadvantaged groups.

Finally, a major limitation of the current research is that, while it provides insight into the representations of elite, university-educated participants, it cannot be generalized to the less educated, less fortunate majorities in subSaharan Africa. While it is true that politics in Africa, as in most developing societies, is elitedriven, future research should investigate historical representations of people with different socioeconomic and educational backgrounds. This is easier said than done, and would require different methods. Getting samples from non-Anglophone sub-Saharan Africa was a daunting task even for our research. The participants in this research were not used to answering surveys and were not familiar with quantitative scales, so we opted for open-ended measures. For most, it was their first participation in empirical research and opportunity to voice their opinions.

Except Cape Verde, all countries in this research are facing extreme poverty and are among the ones with the lowest levels of human development in the 
world. Even if participants were members of an elite, they would have experienced shortages in "basic" things that are taken-for-granted in developed societies. These young adults had hope for the future. In their own words, they foresaw for the future a world with "peace and where everyone will live at ease," "the end of poverty," "electricity and water channels in all villages," "no more poor or illiterate in the world," and "a world where feasting would be a habit." This shows how objective conditions can shape visions of history and the future, an issue that also deserves further research.

African perspectives are almost absent from the current psychological literature, which is "reflective of the historically unequal intercultural exchanges between Western and African cultural heritages and in favour of the former. A greater representation of the African experience in the psychological literature could add to the richness and global relevance of psychology" (Mpofu, 2002 , p. 179). We hope we have contributed a little to this growing richness in crosscultural research.

\section{NOTES}

1. Information in parentheses indicates the nationality and the identification number of the participant.

2. This was done in the software Tri-Deux (Cibois, 2006) since SPSS does not allow this possibility. It involves computing a Burt contingency table crossing all modalities of the three variables with each other (Cibois, 2009). The resulting factor structure is similar.

Manuscript received September 2010 Revised manuscript accepted November 2010 First published online May 2011

\section{REFERENCES}

Bartlett, F. C. (1932). Remembering: A study in experimental and social psychology. Cambridge, UK: Cambridge University Press.

Benzecri, J. P. (1992). Correspondence analysis handbook. New York, NY: Dekker.

Cabecinhas, R., \& Feijó, J. (2010). Collective memories of Portuguese colonial action in Africa: Representations of the colonial past among Mozambicans and Portuguese youths. International Journal of Conflict and Violence, 4, 28-44.

Cibois, Ph. (2006). Trideux 5.0 (software program). Printemps Laboratory, University of Versailles, France.

Cibois, Ph. (2009). Les méthodes d'analyse d'enquête. Paris, France: Presses Universitaires de France.
Deschamps, J. C., Paez, D., \& Pennebaker, J. (2001). Mémoire collective des évenements socio-politiques et culturels: Répresentation sociale du passé à la fin du millenium. Psychologie et Société, 3, 26-35.

Feijó, J. (2009). Do passado colonial à independência: Discursos do semanário Savana nas celebrações das datas históricas de Mocambique. Lisbon, Portugal: Periploi.

Greenacre, M. (2007). Correspondence analysis in practice (2nd ed.). London, UK: Chapman and Hall/CRC.

Halbwachs, M. (1950/1997). La mémoire collective. Paris, France: Albin Michel.

Klein, O., \& Licata, L. (2003). When group representations serve social change: The speeches of Patrice Lumumba during the Congolese decolonization. British Journal of Social Psychology, 42, 571-594.

Licata, L., Klein, O., \& Gély, R. (2007). Mémoire des conflits, conflits de mémoires: Une approche psychosociale et philosophique du rôle de la mémoire collective dans les processus de réconciliation intergroupe. Social Science Information, 46, 563-589.

Liu, J. H., Goldstein-Hawes, R., Hilton, D. J., Huang, L. L., Gastardo-Conaco, C., Dresler-Hawke, E., et al. (2005). Social representations of events and people in world history across twelve cultures. Journal of Cross Cultural Psychology, 36, 171-191.

Liu, J. H., \& Hilton, D. (2005). How the past weighs on the present: Towards a social psychology of histories. British Journal of Social Psychology, 44, 537-556.

Liu, J. H., \& László, J. (2007). A narrative theory of history and identity: Social identity, social representations, society and the individual. In G. Moloney, \& I. Walker (Eds.), Social representations and identity: Content, process and power (pp. 85-107). London, UK: Palgrave Macmillan.

Liu, J. H., Paez, D., Hanke, K., Rosa, A., Hilton, D. J., Sibley, C. G., et al. (in press). Cross-cultural dimensions of meaning in the evaluation of events in world history? Perceptions of historical calamities and progress in cross-cultural data from 30 societies. Journal of Cross Cultural Psychology. Advance online publication. Retrieved August 31, 2010. doi:10.1177/ 0022022110390926.

Liu, J. H., Paez, D., Slawuta, P., Cabecinhas, R., Techio, E., Kokdemir, D., et al. (2009). Representing world history in the 21st Century: The impact of 9-11, the Iraq War, and the nation-state on dynamics of collective remembering. Journal of Cross-Cultural Psychology, 40, 667-692.

Moscovici, S. (1988). Notes towards a description of social representations. European Journal of Social Psychology, 18, 211-250.

Mpofu, E. (2002). Psychology in sub-Saharan Africa: Challenges, prospects and promises. International Journal of Psychology, 37(3), 179-186.

Pennebaker, J., Paez, D., \& Deschamps, J. C. (2006). The social psychology of history: Defining the most important events of the last 10, $100 \& 1000$ years. Psicología Política, 32, 15-32.

Pennebaker, J., Paez, D., \& Rimé, B. (1997). Collective memory of political events. Mahwah, NJ: Lawrence Erlbaum Associates.

Said, E. (1985). Orientalism. Harmondsworth, UK: Penguin. 
Stengers, J. (1989). Congo: Mythes et réalités: 100 ans d'histoire. Paris, France: Duculot.

Tajfel, H., \& Turner, J. C. (1979). An integrative theory of intergroup conflict. In W. G. Austin, \& S. Worchel (Eds.), The social psychology of intergroup relations (pp. 33-48). Monterey, CA: Brooks/Cole.

Taylor, S. E., \& Brown, J. D. (1988). Illusion and wellbeing: A social psychological perspective on mental health. Psychological Bulletin, 103(2), 193-210.

United Nations Development Programme (2009). Human Development Report 2009. New York, NY: Palgrave Macmillan.
Volpato, C., \& Licata, L. (2010). Introduction: Collective memories of colonial violence. International Journal of Conflict and Violence, 4, $1-10$.

Weinstein, W., \& Schrire, R. (1976). Political conflict and ethnic strategies: A case study of Burundi. New York, NY: Maxwell School of Citizenship and Public Affairs.

Wertsch, J. V. (2002). Voices of collective remembering. Cambridge, UK: Cambridge University Press.

Woodward, J. A., Bonnett, D. G., \& Brecht, M. L. (1990). Introduction to linear models and experimental design. San Diego, CA: Harcourt Brace Jovanovich. 